\title{
Model simulation of the carbonate chemistry in the microenvironment of symbiont bearing foraminifera
}

\author{
Dieter A. Wolf-Gladrow ${ }^{*}$, Jelle Bijma ${ }^{1}$, Richard E. Zeebe ${ }^{2}$ \\ Alfred-Wegener-Inst. fur Polar und Meeresforschung, Postfach 1201 61, 27515 Bremerhaven, Germany
}

Received 16 July 1997; accepted 28 August 1998

\begin{abstract}
Foraminifera are the most important source of information for oceanographic and climatic reconstruction on glacial-interglacial as well as on much longer time-scales. The information is contained in the chemical composition, especially the isotopic ratios, of the calcitic shells (e.g., $\delta^{11} \mathrm{~B}, \delta^{13} \mathrm{C}, \delta^{18} \mathrm{O}$ ). Based on the assumption that our understanding of the major parameters controlling stable isotope incorporation is complete, these geochemical proxies have been used to reconstruct glacial ice volumes, sea surface and deep water temperatures, ocean circulation changes and shifts between carbon reservoirs. However, recent laboratory experiments have demonstrated that the $\delta^{13} \mathrm{C}$ and $\delta^{18} \mathrm{O}$ are not only strongly dependent on the carbonate chemistry of the culture medium but that the so-called 'vital-effects' are probably mediated via perturbations of the local carbonate system. These findings have an important impact on the interpretation of isotope data. For instance, the carbonate system of the glacial ocean was quite different from that of the Holocene and since the onset of the industrial revolution the carbonate chemistry of the surface water must have changed drastically. As a first step towards a better understanding of the isotopic fractionation processes we present results of a diffusion-reaction model of the carbonate system $\left(\mathrm{CO}_{2}, \mathrm{HCO}_{3}^{-}, \mathrm{CO}_{3}^{2-}, \mathrm{H}^{+}, \mathrm{OH}^{-}, \mathrm{B}(\mathrm{OH})_{3}, \mathrm{~B}(\mathrm{OH})_{4}^{-}\right)$in the microenvironment (the diffusive boundary layer) of living planktic foraminifera. The carbon fluxes associated with the main life processes (calcification, respiration and symbiont photosynthesis) lead to substantial perturbations in $\mathrm{pH}$ and significant shifts in the concentrations of $\mathrm{CO}_{2}, \mathrm{CO}_{3}^{2-}$ and other components in the vicinity of the foraminifer. Consequently, the carbonate chemistry of the ambient environment is quite different from that of the bulk sea water. Comparison with $\mathrm{pH}$-microelectrode measurements confirm our numerical results. Our results further demonstrate that the symbionts must use bicarbonate as an additional carbon source for photosynthesis as the calculated $\mathrm{CO}_{2}$ fluxes are not sufficient to support measured rates of oxygen evolution. The simulations also show that for the fast calcification of Globigerinoides sacculifer the supply of carbonate ions is insufficient and therefore use of bicarbonate or an internal pool for carbon is required, whereas no such pool is necessary for the much slower calcification in Orbulina universa. (C) 1999 Elsevier Science B.V. All rights reserved.
\end{abstract}

Keywords: foraminifera; sea water carbonate system; Globigerinoides sacculifer; Orbulina universa

\footnotetext{
* Corresponding author. Tel.: +49-471-4831-824; Fax: +49-471-4831-425; E-mail: wolf@awi-bremerhaven.de

${ }^{1}$ Present address: Geosciences, University of Bremen, P.O. Box 330 440, D-28334 Bremen, Germany. E-mail: jbijma@uni-bremen.de

${ }^{2}$ E-mail: rzeebe@awi-bremerhaven.de.
} 


\section{Introduction}

Foraminifera are unicellular organisms most of which build calcite shells of roughly $0.5 \mathrm{~mm}$ diameter comprising of a series of chambers around a coiling axis (e.g., Berger, 1969; Signes et al., 1993). They are distributed throughout the entire world oceans, living on or in the sediment or having a planktic habitat. As passive inhabitants of their environment planktic foraminifera are distributed wherever water currents carry them. The geographic distribution of the different species, however, is restricted to global climate belts and five major faunal provinces may be recognized (e.g., Hemleben et al.,
1989). The distribution of species appears to be related to water mass temperature but the factors governing abundance and range are certainly more complex. Planktic foraminifera can be subdivided into those possesing spines radiating out from the central shell (spinose species, see Fig. 1), and those without spines (non-spinose). In general, non-spinose species are herbivorous whereas spinose species are carnivorous. Most non-spinose species are symbiont barren (although some were reported to have a facultative symbiotic relationship with chrysophytes; Gastrich, 1988). On the contrary, most of the spinose species harbor large numbers of algae (in general dinoflagellates) between their spines.
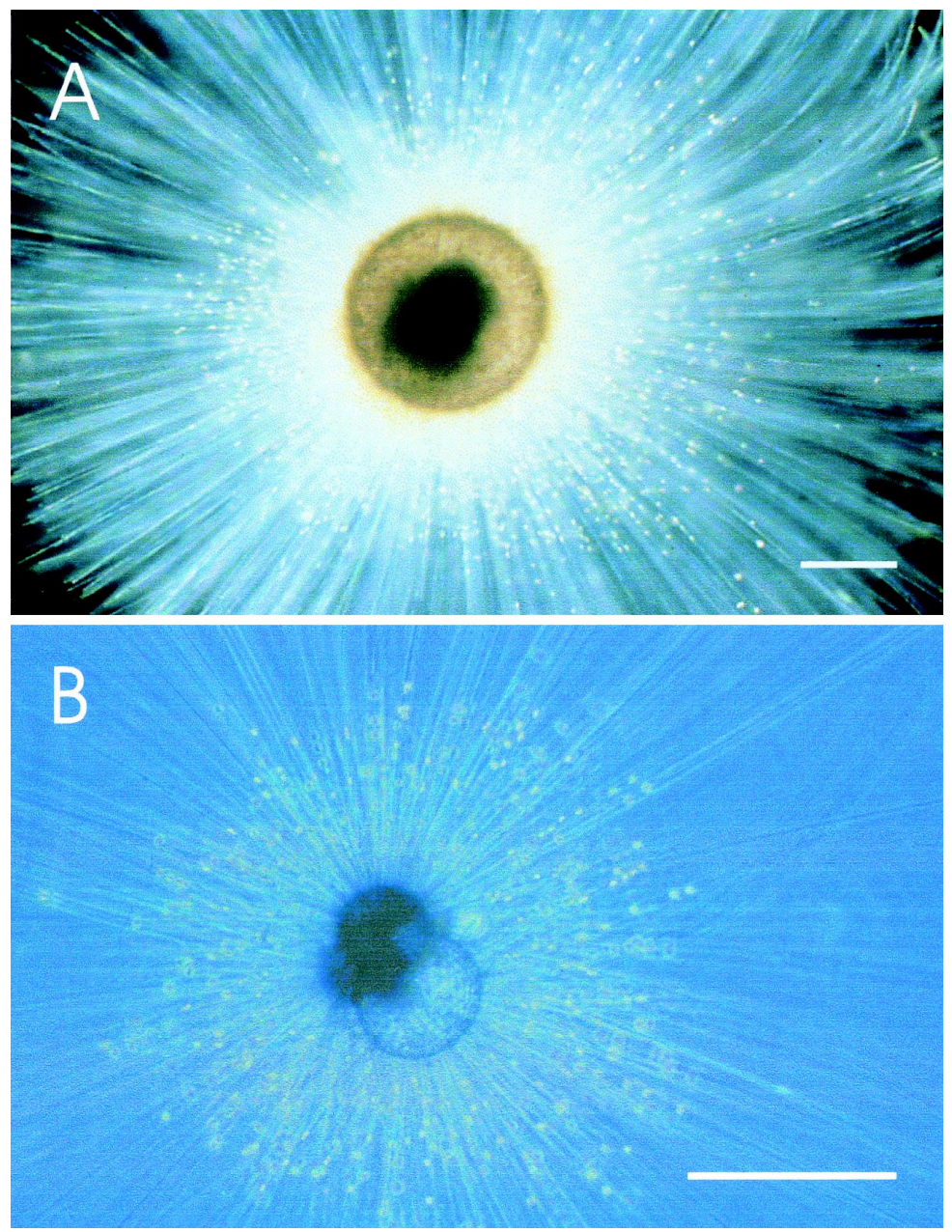

Fig. 1. (A) Microphotograph of $O$. universa d'Orbigny with symbiotic dinoflagellates (photo: H.J. Spero; scale bar $=300 \mu \mathrm{m}$ ). (B) Microphotograph of G. sacculifer (Brady) with symbiotic dinoflagellates (photo: H.J. Spero; scale bar $=300 \mu \mathrm{m}$ ). 
Fossil shells of foraminifera found in deep sea sediments provide one of the most powerful tools to reconstruct the paleo-environment. In modern paleooceanographic or -climatic research, the chemical composition, especially the stable isotopic composition $\left(\delta^{11} \mathrm{~B}, \delta^{13} \mathrm{C}, \delta^{18} \mathrm{O}\right)$, is a major source of information to trace biotic and abiotic parameters of ancient oceans.

The reconstruction of past oceans from analysis of foraminiferal shells is based on the assumption that the signal stored in the shells mirrors the properties of the bulk water mass. Unfortunately, this assumption is not generally true. The impact of life processes of the host-symbiont system such as calcification, respiration and photosynthesis of the symbiotic algae (collectively known as 'vital effects'; e.g., Duplessy et al., 1970) on the fractionation of the stable isotopes has long been neglected. These, however, can strongly modify the signal (e.g., Spero and Williams, 1988; Bijma et al., in press). For both, a symbiont bearing species Orbulina universa and a symbiont barren species Globigerina bulloides it has recently been demonstrated that the isotopic composition of the shells is strongly dependent on the carbonate chemistry of the ambient water (Spero et al., 1997; Bijma et al., in press). These authors proposed that the isotope fractionation induced by the vital effects is mediated via their impact on the ambient carbonate chemistry. Consequently, changes in the carbonate chemistry of the oceanic surface water, from the last glacial maximum (LGM) into the Holocene (Sanyal et al., 1995), could have affected the isotopic composition of planktic foraminifera.

The widespread use of foraminiferal shells in paleoceanography demands a sound understanding of the processes involved during calcite formation. The aim of this paper is to elucidate the interaction of metabolic effects of the foraminifer and the chemical environment. We focus on the carbonate system since the understanding of this diffusion-reaction system during calcite precipitation is a prerequisite for the understanding of the stable carbon isotope composition of foraminiferal shells. Aspects of isotopic fractionation are dealt with in a companion paper (Zeebe et al., 1999). We have developed a mathematical model of the carbonate system within the foraminiferal microenvironment (the diffusive boundary layer around the shell). The model includes chemical reactions, diffusion and uptake or release of the three carbonate species $\mathrm{CO}_{2}, \mathrm{HCO}_{3}^{-}, \mathrm{CO}_{3}^{2-}$ and the two borate compounds $\mathrm{B}(\mathrm{OH})_{3}$ and $\mathrm{B}(\mathrm{OH})_{4}^{-}$, which buffer the shift in $\mathrm{pH}$. Such diffusion-reaction models are also applicable in other strongly perturbed microenvironments such as in Phaeocystis or in marine snow (e.g., Ploug et al., 1997).

\section{Modelled species and life processes}

As model species we have chosen Orbulina universa d'Orbigny (Fig. 1a) and Globigerinoides sacculifer (Brady) (Fig. 1b). Both species are amenable to laboratory treatment and their good conservation potential has left an extensive fossil archive. Much information on habitat, life cycle and isotopic fractionation behavior has been accumulated over the years. In addition, for both species rates of their life processes have been determined recently (Jørgensen et al., 1985; Spero and Williams, 1988; Lea et al., 1995). In particular, O. universa is ideal for culture experiments and numerical modelling. The terminal spherical chamber, which is secreted in the laboratory, comprises up to $95 \%$ of the total calcite, i.e., the stable isotopic composition of the shell is almost exclusively determined by the controlled culture conditions. In addition, the spheres weigh enough to allow mass spectrometer analyses of individual specimens.

The life habitats of $O$. universa and G. sacculifer, which are both associated with dinoflagellate symbionts (Gymnodinium beii), are restricted to the euphotic zone. The symbionts are distributed between and on the spines in a halo around the calcitic shell (compare Fig. 1). Depending on size O. universa harbors between 3000 to 7000 symbionts (Spero and Parker, 1985). Based on chlorophyll-a determinations we assume a similar number of symbionts in $G$. sacculifer (Bijma, 1986). O. universa has a tropical to temperate distribution and the salinity and temperature limits are $23-46$ and $12^{\circ}-31^{\circ} \mathrm{C}$, respectively. G. sacculifer tolerates salinities from $24-47$ and temperatures of $14^{\circ}-31^{\circ} \mathrm{C}$ (Bijma et al., 1990b) and has a tropical-subtropical distribution. Like most spinose species, both are carnivorous and mainly feed on calanoid copepods at a rate of one to two per 
day (Spindler et al., 1984). Upon reaching maturity, G. sacculifer may secrete a unique so called sac-like chamber while $O$. universa always secretes a spherical chamber around the existing trochospiral. Reproduction of both species is tuned to the lunar cycle (Bijma et al., 1990a). Impending gametogenesis is indicated by spine resorption and the secretion of a substantial amount of so called gametogenic (GAM) calcite.

\subsection{Calcification}

The formation of biogenic calcite is a complex process for which several mechanism have been suggested (for a detailed discussion see, for example, ter Kuile, 1991; Lowenstam and Weiner, 1989; Mann et al., 1989). However, independent of the mechanism itself, it is important to realize that three different modes of calcification can be distinguished within planktic foraminifera:

1. Ontogenetic calcification is the periodic addition of chambers along a logarithmic growth spire. According to Hemleben et al. (1987) approximately $90 \%$ of the new chambers in G. sacculifer are formed between midnight and two o'clock in the morning. This is consistent with Anderson and Faber (1984) who claim that most chambers are produced between midnight and noon. Calcification of the chamber itself is completed in about $6 \mathrm{~h}$ (i.e. Bé et al., 1979; Hemleben et al., 1989).

For G. sacculifer Erez (1983) and Anderson and Faber (1984) reported average calcification rates from 0.4 to $3.9 \mathrm{nmol} \mathrm{CaCO}_{3} \mathrm{~h}^{-1}$, respectively. The much lower value found by Erez is probably due to the fact that not all specimens formed chambers.
2. A second mode of calcification is found in mature $O$. universa. The calcification of the adult sphere is more or less continuous but the rates vary within a diurnal cycle. Using ${ }^{48} \mathrm{Ca}$ in pulse chase experiments with adult $O$. universa, calcification rates of 1 and $3 \mathrm{nmol} \mathrm{CaCO}_{3} \mathrm{~h}^{-1}$ in the dark and in the light respectively have been determined (Lea et al., 1995).

3. Gametogenetic calcification, the third mode, is characterized by the fast secretion of a substantial amount of calcite that starts after complete resorption of the spines and may continue to just prior to gamete release. This process adds on average between 3-31\% by weight (Bé, 1980; Bé et al., 1983; Hamilton, 1997) within a few hours to the pregametogenic shell of $G$. sacculifer and $O$. universa.

A compilation of rates of calcification is provided in Table 1.

\subsection{Photosynthesis}

Photosynthetic uptake of carbon by the symbiotic microalgae significantly influences the chemical environment of the foraminifer. The concentration of symbionts and therefore the rates of photosynthesis in the halo around the shell can be much higher than in typical algal bloom situations where the effect of photosynthesis of a single algal cell on the chemical environment, except for $\mathrm{CO}_{2}$, might be negligible (Wolf-Gladrow and Riebesell, 1997). Spero and Parker (1985) estimated that a large O. universa could be 20000 times more productive than an equivalent volume of oligotrophic sea water. At foraminiferal densities of only $5 \mathrm{~m}^{-3}$ their symbionts would contribute about $1 \%$ of the total inor-

Table 1

Measured C fluxes for vital effects of the planktic foraminifera O. universa and G. sacculifer

\begin{tabular}{lllll}
\hline Life process & Species & \multicolumn{2}{l}{ Flux $\left(\mathrm{nmol} \mathrm{C} \mathrm{h}^{-1}\right)$} & Reference \\
\cline { 2 - 3 } & & dark & light & \\
\hline Calcification & O. universa & 1 & 3 & Lea et al. (1995) \\
Calcification & G. sacculifer & 0.4 & $2.6-3.9$ & Erez (1983); Anderson and Faber (1984) \\
Respiration & O. universa & 2.1 & & Spero et al. (1991) \\
Respiration & O. universa & 3.4 & 5.2 & Rink (1996) \\
Respiration & G. sacculifer & 2.7 & 3.0 & J $\varnothing$ rgensen et al. (1985) \\
Photosynthesis & O. universa & & 9.9 & Rink (1996) \\
Photosynthesis & G. sacculifer & & 12.7 & Jørgensen et al. (1985) \\
\hline
\end{tabular}


ganic carbon uptake by all primary producers. An open question is which form of carbon, $\mathrm{CO}_{2}$ or $\mathrm{HCO}_{3}^{-}$, is taken up by the symbionts. While there is strong evidence that many diatoms prefer $\mathrm{CO}_{2}$ instead of $\mathrm{HCO}_{3}^{-}$or $\mathrm{CO}_{3}^{2-}$ as a carbon source (Riebesell et al., 1993; Chen and Durbin, 1994; Rau et al., 1996), it is likely that dinoflagellates also use $\mathrm{HCO}_{3}^{-}$(Hinga, 1992). In Sections 4.2 and 4.4 it will be shown that $\mathrm{CO}_{2}$ alone cannot support measured rates of photosynthesis between 10 and $15 \mathrm{nmol} \mathrm{C}$ $\mathrm{h}^{-1}$. Rates of gross photosynthesis for G. sacculifer were determined by Jørgensen et al. (1985). Values for the carbon uptake of $O$. universa were taken from Spero et al. (1991) and from Rink et al. (1998). A compilation of rates of photosynthesis is provided in Table 1.

\subsection{Respiration}

Respiration of the foraminifer and the symbiotic algae produce $\mathrm{CO}_{2}$ while oxygen is taken up. Whereas foraminifer respiration is a function of its biomass, feeding behavior and probably temperature, respiration by the symbionts may also be driven by the light intensity through photorespiration.

Reported values of respiration refer to the respired $\mathrm{CO}_{2}$ of the total host-symbiont system ('functional autotroph'). Away from the shell, the respired $\mathrm{CO}_{2}$ of the foraminifer and that of the symbiotic algae cannot be distinguished. However, the location of the $\mathrm{CO}_{2}$ release differs for the host and the symbionts. Carbon dioxide released by the foraminifer diffuses through the pores and the aperture(s) of the shell and therefore appears at the shell surface. On the other hand, carbon dioxide released by the symbiotic algae is released within the halo around the shell. These different locations of $\mathrm{CO}_{2}$ production can be distinguished in a model but can hardly be separated with microelectrode measurements. A generally accepted rate for algal dark respiration is $10 \%$ of the maximum rate of gross photosynthesis $\left(P_{\max }\right)$ in the light (Humphrey, 1975). A compilation of known respiration rates is provided in Table 1.

\section{The model}

The diffusion-reaction model for the carbonate system in a spherical geometry has been discussed in detail by Wolf-Gladrow and Riebesell (1997). The model calculates concentration profiles of chemical species of the carbonate system as a function of the distance from the center of the foraminiferal shell. The bulk sea water contains certain concentrations of $\mathrm{CO}_{2}, \mathrm{HCO}_{3}^{-}, \mathrm{CO}_{3}^{2-}, \mathrm{B}(\mathrm{OH})_{3}$, and $\mathrm{B}(\mathrm{OH})_{4}^{-}$depending on the $\mathrm{pH}$. Given the equilibrium values of the chemical reaction constants, the bulk concentrations can be calculated from, for example, total dissolved inorganic carbon $\left(\mathrm{SCO}_{2}\right)$ and alkalinity. The volume of the water mass surrounding the foraminifer is large in comparison to the size of the foraminifer, i.e., far away from the shell $(\sim 3000 \mu \mathrm{m})$ the concentration of all chemical species will equal their bulk values (outer boundary condition). In the close vicinity of the foraminiferal shell, however, where $\mathrm{CO}_{2}$ is released by respiration, carbon is taken up through photosynthesis, and calcite is precipitated, the concentrations of the chemical substances will differ from the bulk medium. The model calculates the concentrations in the vicinity of the shell depending on diffusion, chemical conversion, and the fluxes generated by vital effects.

A schematic representation of the model is given in Fig. 2. The inner boundary is the surface of the shell at $r=R_{1}$ where the inner boundary condition is given by the fluxes of the chemical species, while the outer boundary is chosen to be at $R_{3}=10 \times R_{1}$, where the concentration of each species equals their bulk value. $R_{2}$ is the outer boundary of the symbiotic halo.

\subsection{Spatial and temporal considerations}

The diffusion-reaction model is based on the work of Wolf-Gladrow and Riebesell (1997). The following chemical reactions are taken into account:

$$
\begin{aligned}
& \mathrm{CO}_{2}+\mathrm{H}_{2} \mathrm{O} \underset{k_{-1}}{\stackrel{k_{+1}}{\rightleftharpoons}} \mathrm{H}^{+}+\mathrm{HCO}_{3}^{-} \\
& \mathrm{CO}_{2}+\mathrm{OH}^{-} \quad \underset{k_{-4}}{\stackrel{k_{+4}}{\rightleftharpoons}} \mathrm{HCO}_{3}^{-} \\
& \mathrm{CO}_{3}^{2-}+\mathrm{H}^{+} \quad \underset{k_{-5}}{\stackrel{k_{+5}}{\rightleftharpoons}} \mathrm{HCO}_{3}^{-} \\
& \mathrm{H}_{2} \mathrm{O} \underset{k_{-6}}{\stackrel{k_{+6}}{\rightleftharpoons}} \mathrm{H}^{+}+\mathrm{OH}^{-} \\
& \mathrm{B}(\mathrm{OH})_{3}+\mathrm{H}_{2} \mathrm{O} \underset{k_{-7}}{\stackrel{k_{+7}}{\rightleftharpoons}} \mathrm{B}(\mathrm{OH})_{4}^{-}+\mathrm{H}^{+} .
\end{aligned}
$$




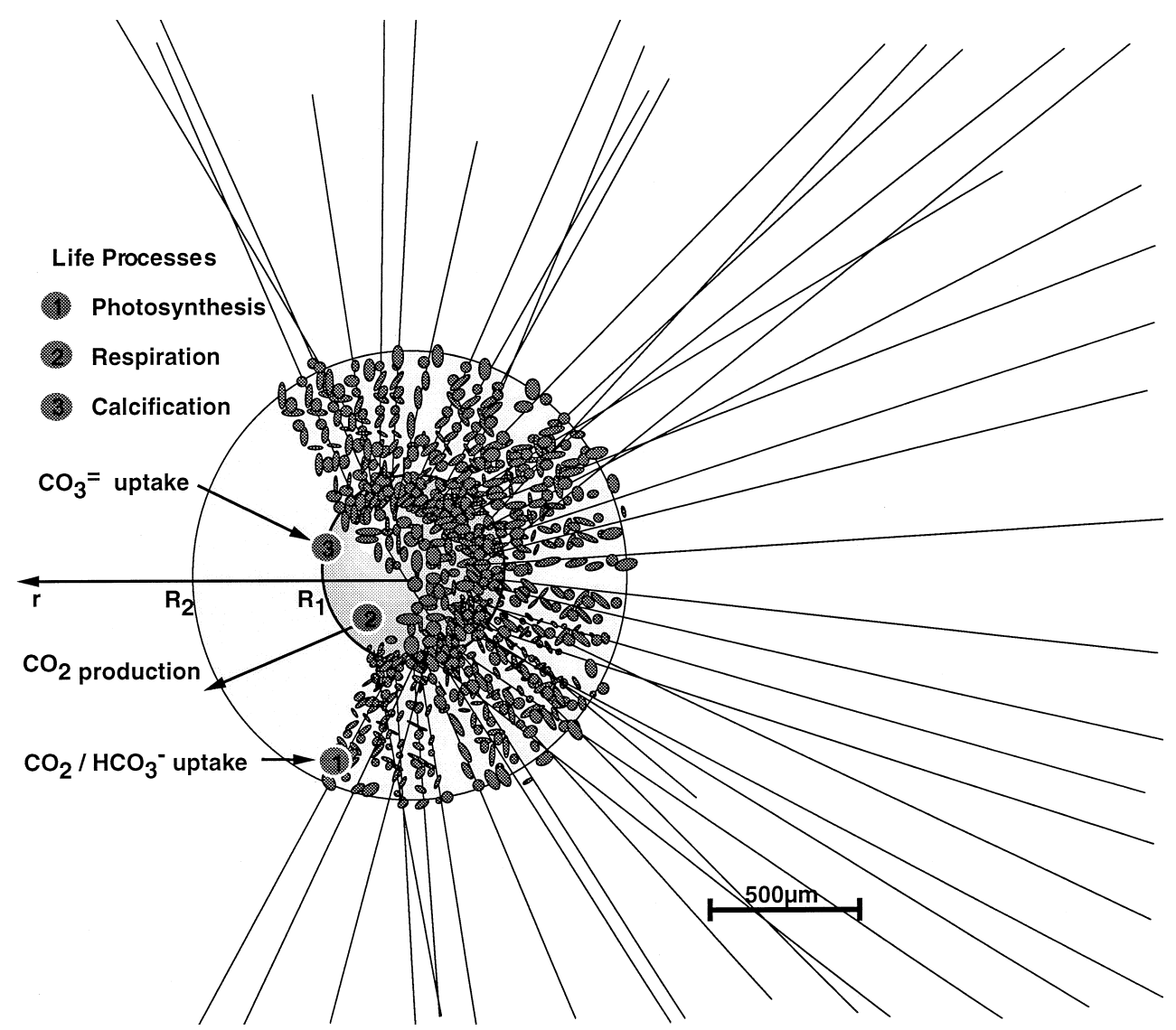

Fig. 2. Schematic view of a symbiont bearing foraminifer. The associated life processes, namely, calcification, respiration and photosynthesis of the symbionts all influence the carbonate system in the microenvironment of the foraminifer. $R_{1}$ is the radius of the outer calcite shell. The symbionts photosynthesize in a halo between $R_{1}$ and $R_{2}$.

Spherical symmetry is assumed which is a very good approximation for adult $O$. universa. Because G. sacculifer secretes a trochospiral shell, one would expect that spherical symmetry may not hold for $G$. sacculifer. However, Jørgensen et al. (1985) showed that measured profiles of oxygen around the shell of G. sacculifer had nevertheless a spherical symmetry. Unpublished $\mathrm{pH}$ profiles (kindly provided by B.B. Jørgensen) confirm this spherical distribution. The shell radius is 200 and $267 \mu \mathrm{m}$ for G. sacculifer and $O$. universa, respectively. In both cases the symbionts are distributed in a halo with a width of 500 $\mu \mathrm{m}$ starting at the shell surface.

Concentration profiles are calculated as a function of the distance from the center of the sphere $r$. The time needed to establish a steady state can be estimated by the diffusional time scale $\tau=l^{2} / D$, where $l \approx 300 \mu \mathrm{m}$ is the boundary layer thickness (equal to the radius of the outer shell of the foraminifera), and $D \approx 2 \times 10^{-9} \mathrm{~m}^{2} \mathrm{~s}^{-1}$ is the diffusion coefficient for $\mathrm{CO}_{2}$. Given these values, $\tau=45 \mathrm{~s}$. The time scale for the slowest reaction, i.e., conversion from $\mathrm{HCO}_{3}^{-}$ to $\mathrm{CO}_{2}$ is in the order of $100 \mathrm{~s}$. These time scales correspond well to the time of about $1 \mathrm{~min}$ reported by Jørgensen et al. (1985) for a 0.1 unit change in $\mathrm{pH}$ during measurements of photosynthetic rates. Since this time is small compared to typical time scales of calcite precipitation, respiration or photosynthesis in the natural environment (hours or days) a steady state of the fluxes will be assumed. Thus, 
the basic equations of the model are of the following form:

$0=\frac{\partial c(r, t)}{\partial t}=$ Diffusion + Reaction + Uptake

where $c(r, t)$ is the concentration of a species of the carbonate system. Specific sources and sinks have been added for the various life processes. The complete equations of the model read:

$\mathrm{CO}_{2}$ :

$$
\begin{aligned}
0= & \frac{\mathrm{D}_{\mathrm{CO} 2}}{r^{2}} \frac{\mathrm{d}}{\mathrm{d} r}\left(r^{2} \frac{\mathrm{d}\left[\mathrm{CO}_{2}\right]}{\mathrm{d} r}\right)+\left(k_{-1}\left[\mathrm{H}^{+}\right]+k_{-4}\right) \\
& \times\left[\mathrm{HCO}_{3}^{-}\right]-\left(k_{+1}+k_{+4}\left[\mathrm{OH}^{-}\right]\right)\left[\mathrm{CO}_{2}\right] \\
& +f_{\mathrm{res}}^{\mathrm{CO}_{2}}(r)-f_{\mathrm{phs}}^{\mathrm{CO}_{2}}(r)
\end{aligned}
$$

$\mathrm{HCO}_{3}^{-}$:

$$
\begin{aligned}
0= & \frac{D_{\mathrm{HCO}_{3}}}{r^{2}} \frac{\mathrm{d}}{\mathrm{d} r}\left(r^{2} \frac{\mathrm{d}\left[\mathrm{HCO}_{3}^{-}\right]}{\mathrm{d} r}\right)+k_{+1}\left[\mathrm{CO}_{2}\right] \\
& -k_{-1}\left[\mathrm{H}^{+}\right]\left[\mathrm{HCO}_{3}^{-}\right]+k_{+4}\left[\mathrm{CO}_{2}\right]\left[\mathrm{OH}^{-}\right] \\
& -k_{-4}\left[\mathrm{HCO}_{3}^{-}\right]+k_{+5}\left[\mathrm{H}^{+}\right]\left[\mathrm{CO}_{3}^{2-}\right] \\
& -k_{-5}\left[\mathrm{HCO}_{3}^{-}\right]-f_{\mathrm{phs}}^{\mathrm{HCO}_{3}^{-}}(r)
\end{aligned}
$$

$\mathrm{CO}_{3}^{2-}$ :

$$
\begin{aligned}
0= & \frac{D_{\mathrm{CO}_{3}}}{r^{2}} \frac{\mathrm{d}}{\mathrm{d} r}\left(r^{2} \frac{\mathrm{d}\left[\mathrm{CO}_{3}^{2-}\right]}{\mathrm{d} r}\right)+k_{-5}\left[\mathrm{HCO}_{3}^{-}\right] \\
& -k_{+5}\left[\mathrm{H}^{+}\right]\left[\mathrm{CO}_{3}^{2-}\right]
\end{aligned}
$$

$\mathrm{H}^{+}$:

$$
\begin{aligned}
0= & \frac{D_{\mathrm{H}}}{r^{2}} \frac{\mathrm{d}}{\mathrm{d} r}\left(r^{2} \frac{\mathrm{d}\left[\mathrm{H}^{+}\right]}{\mathrm{d} r}\right)+\left(k_{-5}-k_{-1}\left[\mathrm{H}^{+}\right]\right) \\
& \times\left[\mathrm{HCO}_{3}^{-}\right]+k_{+1}\left[\mathrm{CO}_{2}\right]-k_{+5}\left[\mathrm{H}^{+}\right]\left[\mathrm{CO}_{3}^{2-}\right] \\
& +k_{+6}-k_{-6}\left[\mathrm{H}^{+}\right]\left[\mathrm{OH}^{-}\right]+k_{+7}\left[\mathrm{~B}(\mathrm{OH})_{3}\right] \\
& -k_{-7}\left[\mathrm{H}^{+}\right]\left[\mathrm{B}(\mathrm{OH})_{4}^{-}\right]-f_{\mathrm{phs}}^{\mathrm{HCO}_{3}^{-}}(r)
\end{aligned}
$$

$\mathrm{OH}^{-}$:

$$
\begin{aligned}
0= & \frac{D_{\mathrm{OH}}}{r^{2}} \frac{\mathrm{d}}{\mathrm{d} r}\left(r^{2} \frac{\mathrm{d}\left[\mathrm{OH}^{-}\right]}{\mathrm{d} r}\right)+k_{-4}\left[\mathrm{HCO}_{3}^{-}\right] \\
& -k_{+4}\left[\mathrm{CO}_{2}\right]\left[\mathrm{OH}^{-}\right]+k_{+6}-k_{-6}\left[\mathrm{H}^{+}\right]\left[\mathrm{OH}^{-}\right]
\end{aligned}
$$

$\mathrm{B}(\mathrm{OH})_{3}$ :

$$
\begin{aligned}
0= & \frac{D_{\mathrm{B}(\mathrm{OH})_{3}}}{r^{2}} \frac{\mathrm{d}}{\mathrm{d} r}\left(r^{2} \frac{\mathrm{d}\left[\mathrm{B}(\mathrm{OH})_{3}\right]}{\mathrm{d} r}\right) \\
& -k_{+7}\left[\mathrm{~B}(\mathrm{OH})_{3}\right]+k_{-7}\left[\mathrm{H}^{+}\right]\left[\mathrm{B}(\mathrm{OH})_{4}^{-}\right]
\end{aligned}
$$

$\mathrm{B}(\mathrm{OH})_{4}^{-}$:

$$
\begin{aligned}
0= & \frac{D_{\mathrm{B}(\mathrm{OH})_{4}}}{r^{2}} \frac{\mathrm{d}}{\mathrm{d} r}\left(r^{2} \frac{\mathrm{d}\left[\mathrm{B}(\mathrm{OH})_{4}^{-}\right]}{\mathrm{d} r}\right) \\
& +k_{+7}\left[\mathrm{~B}(\mathrm{OH})_{3}\right]-k_{-7}\left[\mathrm{H}^{+}\right]\left[\mathrm{B}(\mathrm{OH})_{4}^{-}\right]
\end{aligned}
$$

where $f_{\text {res }}^{\mathrm{CO}_{2}}$ is the efflux of $\mathrm{CO}_{2}$ due to respiration of the symbionts and $f_{\mathrm{phs}}^{\mathrm{CO}_{2}}$ is the uptake of $\mathrm{CO}_{2}$ due to photosynthesis of the symbionts. The rate constants $k_{\nu}$ and the diffusion coefficients $D_{\mu}$ and their dependence on temperature and salinity are discussed in Wolf-Gladrow and Riebesell (1997). The sources, sinks and boundary conditions will be discussed in the following sections.

\subsection{Calcification}

Laboratory experiments (Bijma et al., in press) have shown that the shell weight of $O$. universa decreases with decreasing concentrations of $\mathrm{CO}_{3}^{2-}$. Since the change in bicarbonate is small in comparison to the change in carbonate it is assumed that calcification at the surface of the shell consumes $\mathrm{CO}_{3}^{2-}$ ions according to the chemical reaction

$\mathrm{Ca}^{2+}+\mathrm{CO}_{3}^{2-} \rightleftharpoons \mathrm{CaCO}_{3}$

On the other hand, biological calcification is often described by the overall reaction

$\mathrm{Ca}^{2+}+2 \mathrm{HCO}_{3}^{-} \rightleftharpoons \mathrm{CaCO}_{3}+\mathrm{CO}_{2}+\mathrm{H}_{2} \mathrm{O}$

where $\mathrm{HCO}_{3}^{-}$is assumed to be the source for calcite precipitation. Since the uptake of $\mathrm{HCO}_{3}^{-}$ions is another possible pathway for calcification, model calculations for $\mathrm{HCO}_{3}^{-}$uptake have been included (see Section 4.5). In this case, $\mathrm{CO}_{2}$ is released at the surface of the foraminiferal shell. In the model, the additional $\mathrm{CO}_{2}$ produced by calcification was added to the respired $\mathrm{CO}_{2}$ of the foraminifera (as a boundary condition). 


\subsection{Photosynthesis}

Whereas $\mathrm{CO}_{2}$ may be the primary source of inorganic carbon for many free living algae (no $\mathrm{CO}_{2}$ limitation at typical $\mathrm{pH}$ values of 8.2), symbiotic dinoflagellates also seem to utilize $\mathrm{HCO}_{3}^{-}$in the $\mathrm{CO}_{2}$ depleted microenvironment of the foraminifer $\left(\mathrm{CO}_{2}\right.$ limitation). Measured photosynthetic rates indicate that the carbon demand of the dense algal population within the small volume of the symbiont halo cannot be met by $\mathrm{CO}_{2}$ uptake alone. For a given photosynthetic rate (up to $12.7 \mathrm{nmol} \mathrm{C} \mathrm{h}^{-1}$ ), the total carbon uptake is thus divided into two parts: $\mathrm{CO}_{2}$ and $\mathrm{HCO}_{3}^{-}$uptake. In the model, the $\mathrm{CO}_{2}$ uptake is described via a Michaelis-Menten kinetic, while the $\mathrm{HCO}_{3}^{-}$uptake was calculated as the difference between the total carbon uptake and the $\mathrm{CO}_{2}$ uptake.

\subsubsection{Total carbon uptake}

The carbon uptake of the symbionts is included in the model equations as a sink of $\mathrm{CO}_{2}$ and $\mathrm{HCO}_{3}^{-}$. To derive an expression that takes the radial distribution of the symbionts into account we utilized information about the total carbon uptake through photosynthesis $F_{\mathrm{P}}$, and the radial distribution of photosynthesis in the symbiont swarm $f_{\mathrm{P}}(r)$. The total carbon uptake is given by measurements of the photosynthetic rate (determined from oxygen release during photosynthesis). The radial distribution of photosynthesis is described by a $1 / r^{2}$ dependence $\left(f_{\mathrm{P}}(r) \times r^{2} \approx\right.$ const.; Jørgensen et al., 1985). The carbon uptake $f_{\mathrm{P}}(r)$ at distance $r\left(\mathrm{~mol} \mathrm{~s} \mathrm{~s}^{-1} \mathrm{~m}^{-3}\right)$ integrated over the volume of the photosynthetic region must equal the total carbon uptake $F_{\mathrm{P}}$ (mol $\left.\mathrm{s}^{-1}\right)$ :

$\int_{V} f_{\mathrm{P}}(r) \mathrm{d} V=F_{\mathrm{P}}$.

The function

$f_{\mathrm{P}}(r)=\frac{F_{\mathrm{P}}}{\left(R_{2}-R_{1}\right) 4 \pi r^{2}}$

is the unique solution that fulfills the constraints.

\subsubsection{Michaelis-Menten kinetics for $\mathrm{CO}_{2}$}

Model experiments indicate that the total carbon uptake by the symbionts cannot be met by $\mathrm{CO}_{2}$ alone (Sections 4.2 and 4.4). The calculated $\mathrm{CO}_{2}$ concentration within the halo of the symbionts became negative when realistic values for the total carbon uptake (up to $12.7 \mathrm{nmol} \mathrm{h}^{-1}$ ) were used as input parameters of the model. The ambient $\mathrm{CO}_{2}$ concentration of $10-12 \mu \mathrm{mol} \mathrm{kg}^{-1}$ is too small, and the conversion from $\mathrm{HCO}_{3}^{-}$to $\mathrm{CO}_{2}$ too slow, to supply enough molecular $\mathrm{CO}_{2}$ to the photosynthesizing algal cells. Thus, we must conclude that the dinoflagellates utilize both $\mathrm{CO}_{2}$ and $\mathrm{HCO}_{3}^{-}$. In the model, the total carbon uptake at distance $r$ is therefore calculated as the sum of the $\mathrm{CO}_{2}$ and the $\mathrm{HCO}_{3}^{-}$uptake.

$f_{\mathrm{P}}(r)=f_{{\mathrm{P}, \mathrm{CO}_{2}}_{2}}(r)+f_{{\mathrm{P}, \mathrm{HCO}_{3}^{-}}^{-}}(r)$

The $\mathrm{CO}_{2}$ uptake is described by a Michaelis-Menten kinetic

$Q_{\mathrm{CO}_{2}}=\frac{V_{\max }\left[\mathrm{CO}_{2}\right]}{K_{\mathrm{s}}+\left[\mathrm{CO}_{2}\right]}$

where $Q_{\mathrm{CO}_{2}}$ is the $\mathrm{CO}_{2}$ flux into the algal cell, $V_{\max }$ is the maximum flux rate at high $\mathrm{CO}_{2}$ concentrations (set to the maximum observed uptake rates, i.e., $V_{\max }=12.7 \mathrm{nmol} \mathrm{h}^{-1}$ for $G$. sacculifer and $V_{\max }=$ $10 \mathrm{nmol} \mathrm{h}^{-1}$ for $O$. universa) and $K_{\mathrm{s}}$ is the half saturation constant for $\mathrm{CO}_{2}$ which has been set arbitrarily to $5 \mu \mathrm{mol} \mathrm{kg} \mathrm{kg}^{-1}$. The $\mathrm{CO}_{2}$ uptake at distance $r$ is

$$
\begin{aligned}
f_{\mathrm{P}, \mathrm{CO}_{2}}(r)= & \frac{F_{\mathrm{P}}}{\left(R_{2}-R_{1}\right) 4 \pi r^{2}} \\
& \times\left\{\frac{\left[\mathrm{CO}_{2}\right](r)}{K_{\mathrm{s}}+\left[\mathrm{CO}_{2}\right](r)}\right\}
\end{aligned}
$$

while the $\mathrm{HCO}_{3}^{-}$uptake is given by the difference between the total carbon uptake and the $\mathrm{CO}_{2}$ uptake at distance $r$ :

$$
\begin{aligned}
f_{\mathrm{P}, \mathrm{HCO}_{3}^{-}}(r)= & \frac{F_{\mathrm{P}}}{\left(R_{2}-R_{1}\right) 4 \pi r^{2}} \\
& \times\left\{1-\frac{\left[\mathrm{CO}_{2}\right](r)}{K_{\mathrm{s}}+\left[\mathrm{CO}_{2}\right](r)}\right\} .
\end{aligned}
$$

To keep electric charge neutrality the uptake of $\mathrm{HCO}_{3}^{-}$has to be accompanied by the uptake of cations or the release of anions. In the model the uptake of $\mathrm{HCO}_{3}^{-}$is compensated for by an uptake of 
an equal amount (in mol units) of hydrogen ions. This uptake of $\mathrm{H}^{+}$proved to be equivalent to the release of $\mathrm{OH}^{-}$because model results were indistinguishable for both scenarios.

\subsection{Respiration}

The $\mathrm{CO}_{2}$ which is produced by respiration of the foraminifera is released at the surface of the shell. This respired $\mathrm{CO}_{2}$ represents the inner boundary condition for $\mathrm{CO}_{2}$. On the other hand, respired $\mathrm{CO}_{2}$ of the symbiotic algae is released within a part of the model area that extends from the shell to the outer edge of the symbiont halo $(\approx 800 \mu \mathrm{m})$. Thus, it represents a source of $\mathrm{CO}_{2}$. However, in the light it is rapidly recycled into the photosynthetic pathway.

\section{Results}

In the following sections we present numerical experiments utilizing only one active process at a time in order to increase our understanding of the carbonate system dynamics in the foraminifer microenvironment. Thus, in experiments I, II and III we implemented calcification, photosynthesis or respiration respectively. Numerical experiments IV and V for G. sacculifer (Section 4.4) and VI and VII for $O$. universa (Section 4.6) include several fluxes derived from observations (Table 1). Experiments $\mathrm{I}-\mathrm{V}$ were run for a sea water temperature of $24.5^{\circ} \mathrm{C}$, a salinity of 40.7 , and a bulk $\mathrm{pH}$ of 8.25 as given by Jørgensen et al. (1985).

Experiments VI and VII were run at $20^{\circ} \mathrm{C}, 33.5$ salinity and a bulk pH of 8.3 (see Rink, 1996 and Rink et al., 1998). The bulk concentration of the total dissolved inorganic carbon $\left(\sum \mathrm{CO}_{2}\right)$ was set at a typical surface value of ca. $2200 \mu \mathrm{mol} \mathrm{kg}{ }^{-1}$. The values for the fluxes of life processes alone (I-III) correspond to the fluxes for the light experiment $(\mathrm{V})$ for $G$. sacculifer. This approach permits a direct comparison of the influence of a single vital effect as well as combinations of such vital effects.

\subsection{Calcification}

The effect of calcification on the microenvironment is investigated in experiment I. The calcifica- tion rate of $3.25 \mathrm{nmol} \mathrm{C} \mathrm{h} \mathrm{h}^{-1}$ is comparable to the observed values for G. sacculifer in the light (Table 1). In this model calculation it was assumed that $\mathrm{CO}_{3}^{2-}$ (and not $\mathrm{HCO}_{3}^{-}$) is used for calcification. The effect of $\mathrm{HCO}_{3}^{-}$uptake will be discussed in Section 4.5. The resulting distributions of $\mathrm{CO}_{2}, \mathrm{HCO}_{3}^{-}$, $\mathrm{CO}_{3}^{2-}$, and $\mathrm{pH}$ are shown in Fig. 3 (solid lines). Due to the uptake of carbonate ions the $\mathrm{CO}_{3}^{2-}$ concentration decreases from the bulk value of $329 \mu \mathrm{mol}$ $\mathrm{kg}^{-1}$ to $92 \mu \mathrm{mol} \mathrm{kg}{ }^{-1}$ at the surface of the shell. The perturbation of the $\mathrm{CO}_{3}^{2-}$ distribution leads to conversion from $\mathrm{HCO}_{3}^{-}$to $\mathrm{CO}_{3}^{2-}$ :

$\mathrm{HCO}_{3}^{-} \rightarrow \mathrm{CO}_{3}^{2-}+\mathrm{H}^{+}$.

As a consequence of this conversion hydrogen ions are produced which explain the decrease in $\mathrm{pH}$. The $\mathrm{CO}_{2}$ concentration increases slightly at the shell but shows little response because the conversion from $\mathrm{HCO}_{3}^{-}$to $\mathrm{CO}_{2}$ is slow. It should be noted that the calcification rates of Anderson and Faber (1984) are averaged hourly rates over a period of 24 to $72 \mathrm{~h}$ incubation with ${ }^{45} \mathrm{Ca}$. Consequently, if it is assumed that calcification of a chamber in G. sacculifer takes only $6 \mathrm{~h}$ on the average, the actual calcification rates are much higher and as high as $4 \times 3.9=15.6 \mathrm{nmol}$ $\mathrm{CaCO}_{3} \mathrm{~h}^{-1}$. The calculations show that the maximum $\mathrm{Ca}^{2+}$ flux is $74 \mathrm{nmol} \mathrm{h}^{-1}$ and the maximum $\mathrm{CO}_{3}^{2-}$ flux is ca. $5 \mathrm{nmol} \mathrm{h}^{-1}$. Thus, calcification in foraminifera is limited by the availability of carbonate and the high calcification rates for G. sacculifer can only be explained if bicarbonate is (also) used or if a concentrating mechanism (e.g., internal pool) is assumed. Indeed, several authors have claimed the existence of an inorganic carbon pool (e.g., ter Kuile and Erez, 1988) or a $\mathrm{Ca}^{2+}$ pool (e.g., Anderson and Faber, 1984). In contrast, as calcification in $O$. universa is continuous and well below $5 \mathrm{nmol} \mathrm{h}^{-1}$ there is no need for an internal pool. Pulse chase experiments with stable isotopes $\left({ }^{48} \mathrm{Ca}\right.$ and $\left.{ }^{13} \mathrm{C}\right)$ demonstrated that this species does indeed not have an internal pool for $\mathrm{Ca}^{2+}$ (Lea et al., 1995) nor for inorganic carbon (Bijma et al., in press). The effect of different carbon sources for calcification is discussed in Section 4.5.

\subsection{Photosynthesis}

The effect of photosynthesis on the microenvironment is investigated in experiment II. The photosyn- 

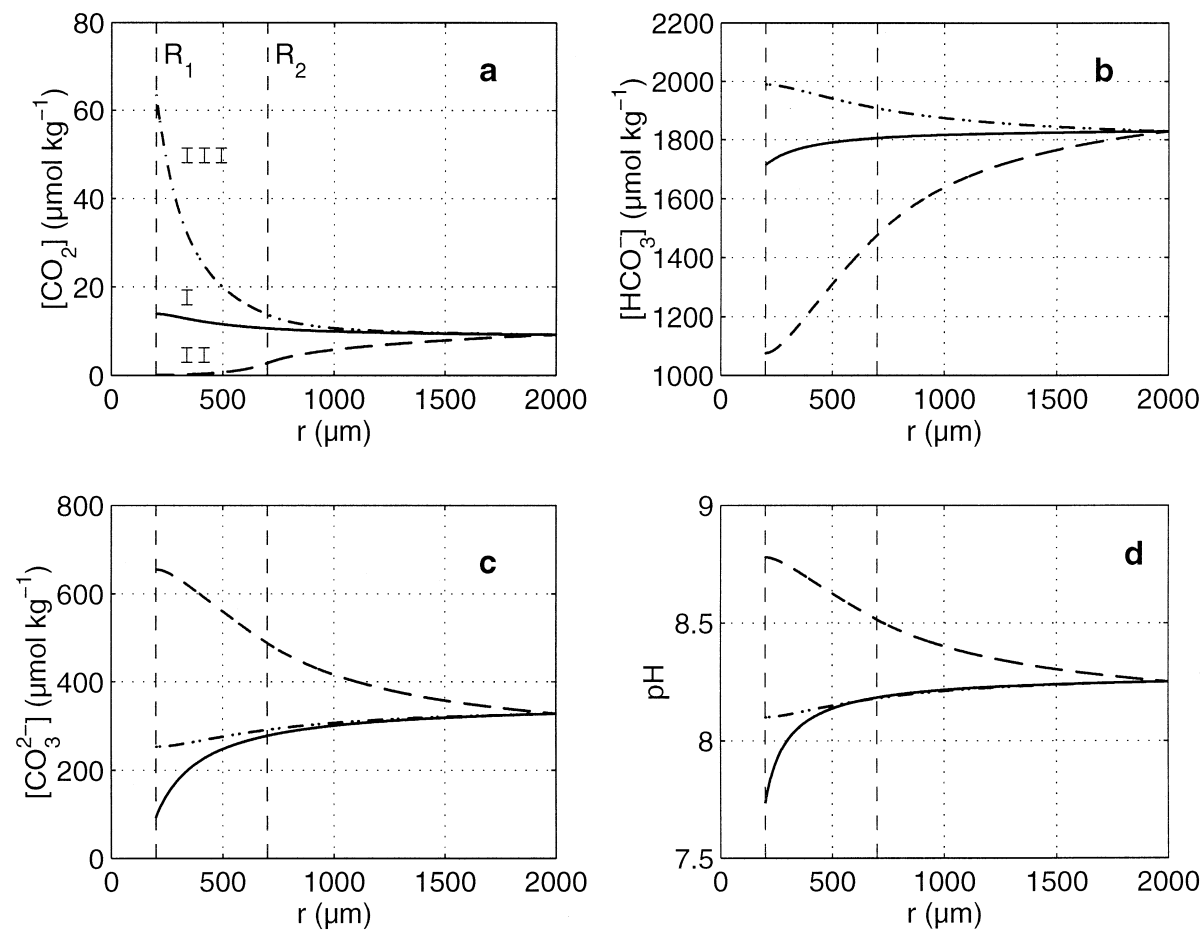

Fig. 3. Modelled profiles of (a) $\mathrm{CO}_{2}$, (b) $\mathrm{HCO}_{3}^{-}$, (c) $\mathrm{CO}_{3}^{2-}$, and (d) $\mathrm{pH}$ for different vital effects as a function of the distance from the center of the shell $\mathrm{r}$. The solid lines indicate calcification only $\left(3.25 \mathrm{nmol} \mathrm{CO} \mathrm{C}^{2-} \mathrm{h}^{-1}\right)$, dashed lines indicate photosynthesis only (12.7 nmol $\left.\mathrm{C} \mathrm{h}^{-1}\right)$, and dot-dashed lines indicate respiration only $\left(3.0 \mathrm{nmol} \mathrm{CO}_{2} \mathrm{~h}^{-1}\right)$.

thetic rate of $12.7 \mathrm{nmol} \mathrm{C} \mathrm{h}^{-1}$ corresponds to the observed light value for G. sacculifer (Table 1) and is probably one of the highest reported values (see Jørgensen et al., 1985). For this photosynthetic uptake the model calculated $\mathrm{CO}_{2}$ concentrations became negative when carbon dioxide was assumed to be the exclusive source for photosynthesis (a model run without the Michaelis-Menten kinetic for $\mathrm{CO}_{2}$ uptake). Moreover, the carbon demand could not be met by carbon dioxide alone even when additional $\mathrm{CO}_{2}$ was released by respiration (see Section 4.4). The $\mathrm{CO}_{2}$ supply was sufficient only for small uptake rates $<3 \mathrm{nmol} \mathrm{h}{ }^{-1}$. Thus, both $\mathrm{CO}_{2}$ and $\mathrm{HCO}_{3}^{-}$ were assumed to be utilized during photosynthetic uptake.

The results are shown in Fig. 3 (dashed lines). For the chosen photosynthetic uptake rate the $\mathrm{CO}_{2}$ concentration drops to values near zero in the inner part of the halo which is occupied by the symbionts. In addition, the concentration of $\mathrm{HCO}_{3}^{-}$decreases to about $1000 \mu \mathrm{mol} \mathrm{kg}^{-1}$ at the shell which is approxi- mately half of the bulk concentration. This decrease is an enormous perturbation of seawater carbonate chemistry in the vicinity of the host-symbiont system. Conditions at the site of calcite precipitation also differ significantly from the bulk medium where $\sum \mathrm{CO}_{2} \approx 1700 \mu \mathrm{mol} \mathrm{kg} \mathrm{kg}^{-1}$ at the shell and 2200 $\mu \mathrm{mol} \mathrm{kg}{ }^{-1}$ in the bulk medium. The ratio of $\mathrm{CO}_{2}$ to $\mathrm{HCO}_{3}^{-}$uptake for this experiment is $1: 4.8$. This ratio, however, can vary over a wide range depending on the availability of $\mathrm{CO}_{2}$ which is influenced by parameters such as respiration and photosynthetic uptake. A second reason for the calculated decrease in $\mathrm{HCO}_{3}^{-}$is its conversion to $\mathrm{CO}_{2}$.

\subsection{Respiration of the foraminifer}

The effect of respiration on the microenvironment is investigated in experiment III. The respiration rate of $3.0 \mathrm{nmol} \mathrm{C \textrm {h } ^ { - 1 }}$ is a typical value for $G$. sacculifer as well as for $O$. universa (compare Table 1). The results are shown in Fig. 3 (dot-dashed lines). 
The $\mathrm{CO}_{2}$ concentration of $64 \mu \mathrm{mol} \mathrm{kg}{ }^{-1}$ at the shell surface is a function of the respired $\mathrm{CO}_{2}$ which diffuses through apertures of the shell. This value is about six times higher than the bulk concentration of $9.3 \mu \mathrm{mol} \mathrm{kg} \mathrm{kg}^{-1}$. This additional $\mathrm{CO}_{2}$ reacts with $\mathrm{CO}_{3}^{2-}$ and produces $\mathrm{HCO}_{3}^{-}$and $\mathrm{H}^{+}$. From the reaction

$$
\mathrm{CO}_{2}+\mathrm{OH}^{-} \rightarrow \mathrm{HCO}_{3}^{-}
$$

one sees a decrease in $\mathrm{pH}$ and an increase in $\mathrm{HCO}_{3}^{-}$ which is further augmented by conversion of $\mathrm{CO}_{3}^{2-}$ to $\mathrm{HCO}_{3}^{-}$in response to the lowered $\mathrm{pH}$ (see Fig. 3).

\subsection{The pH-profile in G. sacculifer}

Model results for $\mathrm{pH}$ profiles of a dark and a light experiment for $G$. sacculifer can be directly compared to measured profiles with microelectrodes by Jørgensen et al. (1985). Input parameters of the model are fluxes of the life processes (Table 2). From these parameters the model calculates concentration profiles of the carbon species (including the $\mathrm{pH}$ profile) which in turn can be compared to the measured profile.

\subsubsection{Dark experiment}

Under dark conditions two vital effects have to be considered-respiration of the host-symbiont system and calcification. The total respiration rate as measured by Jørgensen et al. (1985) was $2.7 \mathrm{nmol}$ $\mathrm{CO}_{2} \mathrm{~h}^{-1}$ in the dark which represents the sum of the respired $\mathrm{CO}_{2}$ by the foraminiferan host and the symbiotic algae. The dark respiration of planktic algae is usually of the order of $10 \%$ of the maximum gross photosynthesis (e.g., Humphrey, 1975). Since the reported gross photosynthesis was $18 \mathrm{nmol} \mathrm{O}_{2}$ $\mathrm{h}^{-1}$ the dark respiration of the symbiotic community was set at $1.8 \mathrm{nmol} \mathrm{CO}_{2} \mathrm{~h}^{-1}$, while the respiration of the foraminifera was set at $0.9(=2.7-1.8) \mathrm{nmol}$ $\mathrm{h}^{-1}$. It should be noted that the $\mathrm{O}_{2}: \mathrm{CO}_{2}$ stoichiometry is $\neq 1$ but since no data are available for the host-symbiont system a 1:1 relationship was used as a first approximation. The calcification rate in the dark experiment was $0.4 \mathrm{nmol} \mathrm{C} \mathrm{h}^{-1}$ (Erez, 1983). Model results of the dark simulation are presented in Fig. 4 (solid lines). The combined effect of respiration and calcification leads to a significant increase of $\left[\mathrm{CO}_{2}\right]$ and a decrease of $\left[\mathrm{CO}_{3}^{2-}\right]$ at the foraminiferal shell. The calculated $\mathrm{pH}$ profile which belongs to the equilibrium of fluxes as determined by the model is shown in Fig. 4d (solid line); $\mathrm{pH}$ decreases from 8.25 in the bulk medium to 8.07 at the shell surface. This result is in good agreement with the measured $\mathrm{pH}$ profile (stars in Fig. 4d).

\subsubsection{Light experiment}

In addition to respiration and calcification, the photosynthetic activity of the symbiotic community has to be implemented in the model calculations under light conditions. The measured gross photosynthesis of the symbiotic algae of $G$. sacculifer was $18 \mathrm{nmol} \mathrm{O} \mathrm{O}_{2}^{-1}$. Assuming a symbiont respiration of $1.8 \mathrm{nmol} \mathrm{h}^{-1}$ (see above), the net $\mathrm{O}_{2}$ production by photosynthesis is $16.2 \mathrm{nmol} \mathrm{h}^{-1}$. This value has to be converted to carbon uptake because the simultaneous fixation of nutrients such as nitrogen and phosphorus results in additional release of oxygen. Because no measurements are available for the $\mathrm{O}_{2}$ :C ratio the ratio was assumed to be $138: 108$ which is the mean value for phytoplankton as given by Redfield et al. (1963). The net carbon uptake is therefore $12.7 \mathrm{nmol} \mathrm{h}^{-1}$.

Table 2

Numerical experiments I-VII: Fluxes and boundary conditions

\begin{tabular}{lllcl}
\hline $\begin{array}{l}\text { Numerical } \\
\text { experiment }\end{array}$ & $\begin{array}{l}\text { Calcification } \\
\left(\mathrm{nmol} \mathrm{C} \mathrm{h}^{-1}\right)\end{array}$ & $\begin{array}{l}\text { Respiration } \\
\left(\mathrm{nmol} \mathrm{C} \mathrm{h}{ }^{-1}\right)\end{array}$ & $\begin{array}{l}\text { Photosynthesis } \\
\left(\mathrm{nmol} \mathrm{C} \mathrm{h}{ }^{-1}\right)\end{array}$ & Remarks \\
\hline I & 3.25 & - & - & Fig. 3 (solid line) \\
II & - & - & 12.7 & Fig. 3 (dashed line) \\
III & - & 3.0 & - & Fig. 3 (dot-dashed) \\
IV & 0.4 & 2.7 & - & Fig. 4 (dark) \\
V & 3.25 & 3.0 & 12.7 & Fig. 5 (light) \\
VI & 1 & 3.4 & - & Fig. 7 (dark) \\
VII & 3 & 5.2 & 9.9 & Fig. 8 (light) \\
\hline
\end{tabular}



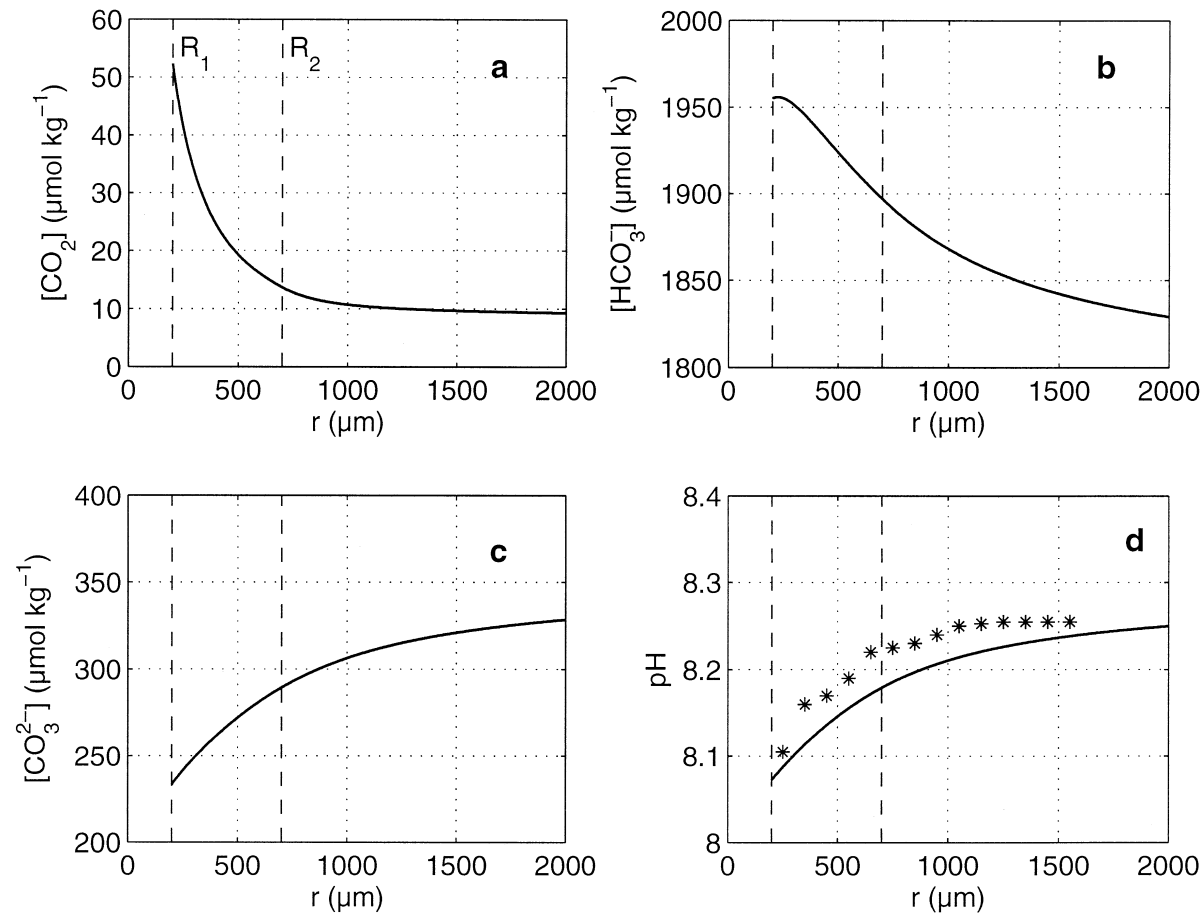

Fig. 4. G. sacculifer: Modelled profiles (solid lines) of (a) $\mathrm{CO}_{2}$, (b) $\mathrm{HCO}_{3}^{-}$, (c) $\mathrm{CO}_{3}^{2-}$, and (d) $\mathrm{pH}$ in the dark as a function of the distance from the center of the shell $r$. The stars in (d) show a $\mathrm{pH}$ profile measured with microelectrodes. The calcification rate is $0.4 \mathrm{nmol} \mathrm{CO}_{3}^{2-}$ $\mathrm{h}^{-1}$, while the respiration of the host-symbiont system is $2.7 \mathrm{nmol} \mathrm{CO}_{2} \mathrm{~h}^{-1}$.

Observed calcification rates in the light are generally higher than in the dark (see Table 1). This is probably a result of photosynthesis which would increase $\mathrm{pH}$ and $\mathrm{CO}_{3}^{2-}$ concentration at the shell (Fig. 3c and d, broken lines).

For the G. sacculifer calcification rate, the mean value of $3.25 \mathrm{nmol} \mathrm{C} \mathrm{h}^{-1}$ of Anderson and Faber (1984) was chosen. The model input for the hostsymbiont respiration in the light was $3 \mathrm{nmol} \mathrm{CO}$ $\mathrm{h}^{-1}$ (Jørgensen et al., 1985). The results of the light experiment are shown in Fig. 5. The radial distribution of $\mathrm{CO}_{2}$ displays the effect of foraminiferal respiration and photosynthetic uptake (Fig. 5a). At the surface of the shell respiration dominates and the $\mathrm{CO}_{2}$ concentration increases to $13.7 \mu \mathrm{mol} \mathrm{kg}{ }^{-1}$. The increase is, however, much less pronounced than for the dark experiment because of the $\mathrm{CO}_{2}$ uptake of the symbiont community which is responsible for the dip in the profile between 300 and $800 \mu \mathrm{m}$. The additional photosynthetic uptake of $\mathrm{HCO}_{3}^{-}$and the chemical conversion of $\mathrm{HCO}_{3}^{-}$to $\mathrm{CO}_{2}$ explains the dramatic decrease of $\mathrm{HCO}_{3}^{-}$towards the shell (Fig. $5 \mathrm{~b})$. The calculated ratio of $\mathrm{CO}_{2}$ to $\mathrm{HCO}_{3}^{-}$uptake is 1:2.6. It should be emphasized that even though the respiration of the foraminifera significantly increases the $\mathrm{CO}_{2}$ concentration at the surface of the shell, the photosynthetic carbon demand could not be met by $\mathrm{CO}_{2}$ uptake alone.

The maximum in the calculated concentration of $\mathrm{CO}_{3}^{2-}$ (Fig. 5c) can be attributed to the combination of photosynthesis (i.e., increase of $\mathrm{pH}$ and $\mathrm{CO}_{3}^{2-}$ ) and direct $\mathrm{CO}_{3}^{2-}$ uptake (decrease directly at the shell surface). The resulting modelled and measured $\mathrm{pH}$ values (solid line and stars, respectively) are compared in Fig. 5d. On the whole, the agreement between model results and measured data is satisfactory. However, the maximum in the calculated $\mathrm{pH}$ profile at about $400 \mu \mathrm{m}$ is not found in the measured data. This disagreement might be explained by the distribution of the symbionts of which a part was located very close to or within the foraminiferal shell during $\mathrm{pH}$ measurements. In contrast, the photosyn- 

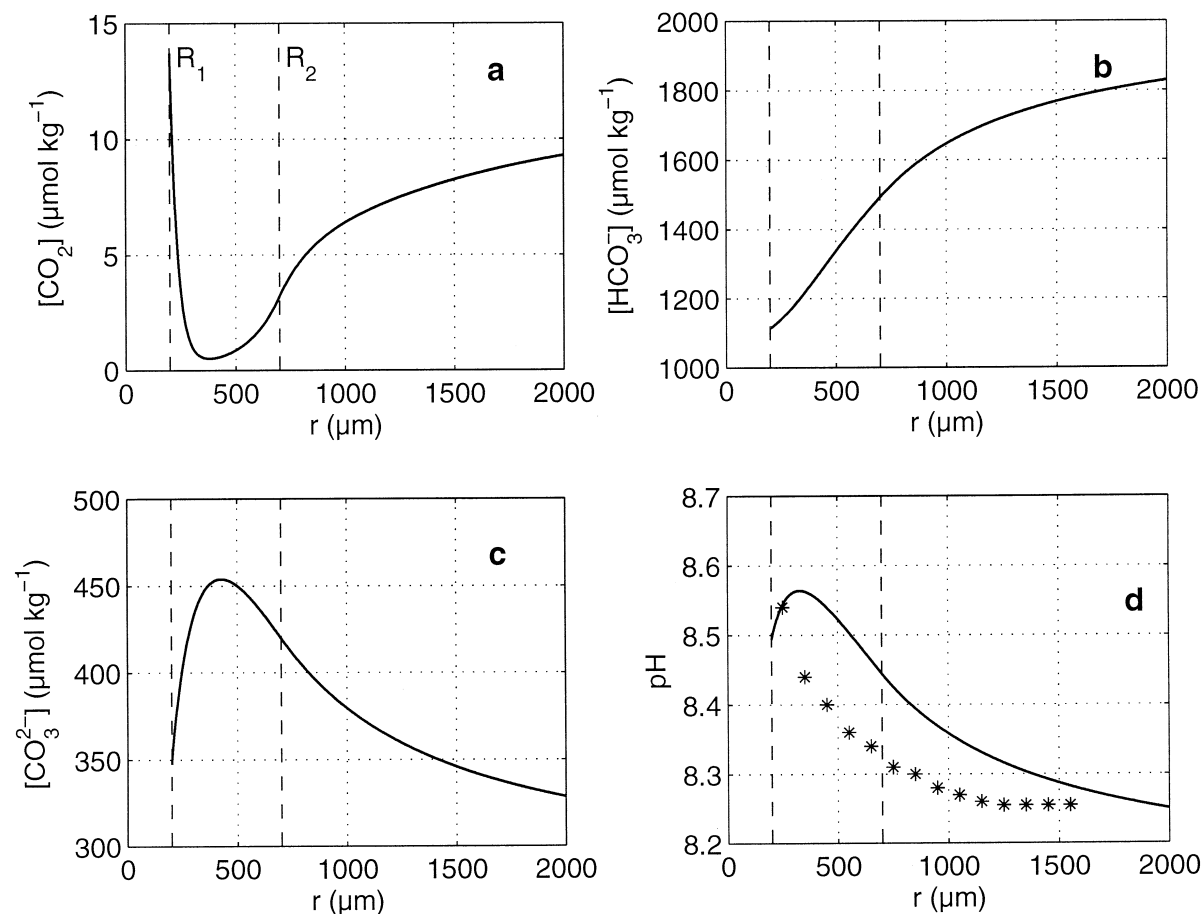

Fig. 5. G. sacculifer: Modelled profiles (solid lines) of (a) $\mathrm{CO}_{2}$, (b) $\mathrm{HCO}_{3}^{-}$, (c) $\mathrm{CO}_{3}^{2-}$, and (d) $\mathrm{pH}$ in the light as a function of the distance from the center of the shell $r$. The stars in (d) show a $\mathrm{pH}$ profile measured with microelectrodes. The calcification rate is $3.25 \mathrm{nmol} \mathrm{CO}_{3}^{2-}$ $\mathrm{h}^{-1}$, the net carbon uptake of symbionts by photosynthesis is $12.7 \mathrm{nmol} \mathrm{C} \mathrm{h}$, and the respiration of the host-symbiont system is $3.0 \mathrm{nmol}$ $\mathrm{CO}_{2} \mathrm{~h}^{-1}$. The value for the photosynthetic uptake corresponds to a gross photosynthesis of $18 \mathrm{nmol} \mathrm{O}_{2} \mathrm{~h}^{-1}$ of the host-symbiont system and an $\mathrm{O}_{2}: \mathrm{CO}_{2}$ ratio of $138: 108$.

thetic uptake in the model was restricted to the volume outside the shell. In addition, the resolution of the micro $\mathrm{pH}$ electrodes is in the order of $50 \mu \mathrm{m}$ and therefore may have missed the maximum close to $R_{1}$.

\subsection{Calcification: $\mathrm{CO}_{3}^{2-}$ or $\mathrm{HCO}_{3}^{-}$uptake}

The carbon source for calcification has been subject of much discussion because $\mathrm{CO}_{3}^{2-}$ and $\mathrm{HCO}_{3}^{-}$ are both likely candidates for calcite precipitation (Section 3.2). In the preceding model experiments uptake of $\mathrm{CO}_{3}^{2-}$ has been assumed. In this section, we investigate the uptake of $\mathrm{HCO}_{3}^{-}$according to the chemical reaction

$\mathrm{Ca}^{2+}+2 \mathrm{HCO}_{3}^{-} \rightleftharpoons \mathrm{CaCO}_{3}+\mathrm{CO}_{2}+\mathrm{H}_{2} \mathrm{O}$.

It can be seen from Eq. (20) that for each mole $\mathrm{CaCO}_{3}$ precipitated 2 mol $\mathrm{HCO}_{3}^{-}$are consumed and
$1 \mathrm{~mol} \mathrm{CO}$ is released. The produced $\mathrm{CO}_{2}$ is assumed to be released at the surface of the foraminiferal shell and is therefore added to the respired $\mathrm{CO}_{2}$. Consequently, the largest differences between model results for $\mathrm{CO}_{3}^{2-}$ and $\mathrm{HCO}_{3}^{-}$uptake is the impact on $\mathrm{CO}_{2}$ concentration. Fig. 6 shows model results of the light experiment for $G$. sacculifer as described in Section 4.4.2 (solid lines) and the calculated profiles for $\mathrm{HCO}_{3}^{-}$uptake (broken lines). Since the input calcification rate is $3.25 \mathrm{nmol}$ $\mathrm{C} \mathrm{h}^{-1}$, the equivalent amount of $\mathrm{CO}_{2}$ is added to the respiration of the host-symbiont system (3 nmol $\mathrm{CO}_{2} \mathrm{~h}^{-1}$ ) resulting in a total release of $6.25 \mathrm{nmol}$ $\mathrm{CO}_{2} \mathrm{~h}^{-1}$. This is reflected in the $\mathrm{CO}_{2}$ concentration at the inner boundary; $\mathrm{CO}_{2}$ increases to $77 \mu \mathrm{mol}$ $\mathrm{kg}^{-1}$. The ratio of photosynthetic $\mathrm{CO}_{2} / \mathrm{HCO}_{3}^{-}$uptake is $1 / 2.6$ for $\mathrm{CO}_{3}^{2-}$ and $1 / 1.5$ for $\mathrm{HCO}_{3}^{-}$as carbon source for calcification. Even though there is an additional $\mathrm{HCO}_{3}^{-}$uptake of $6.5 \mathrm{nmol} \mathrm{h}^{-1}$ for 

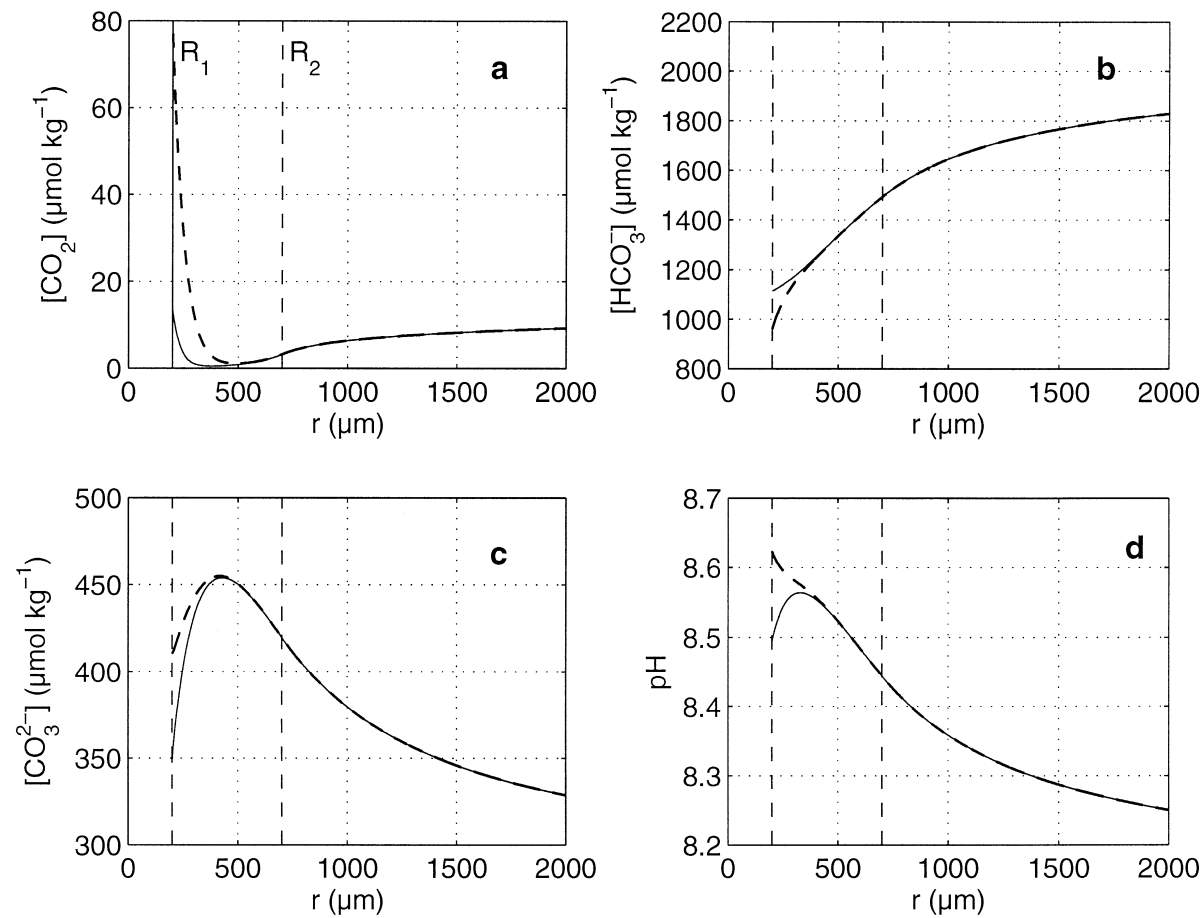

Fig. 6. G. sacculifer: Model results corresponding to Fig. 5 for different carbon sources of the calcification process. Solid lines represent direct uptake of $\mathrm{CO}_{3}^{2-}$, broken lines correspond to $\mathrm{HCO}_{3}^{-}$uptake. While the $\mathrm{CO}_{2}$ concentration increases significantly for $\mathrm{HCO}_{3}^{-}$uptake, small differences in the calculated $\mathrm{pH}$ profiles occur adjacent to the shell.

calcification, the concentration of $\mathrm{HCO}_{3}^{-}$at the shell surface (Fig. 6b, broken line) decreases only marginally in comparison to the $\mathrm{CO}_{3}^{2-}$ uptake scenario (Fig. 6b, solid line). This result can partly be attributed to the photosynthetic uptake (ca. $9 \mathrm{nmol}$ $\mathrm{HCO}_{3}^{-} \mathrm{h}^{-1}$ ) which dominates the distribution of $\mathrm{HCO}_{3}^{-}$to a large degree in both scenarios. In addition, the conversion of $\mathrm{HCO}_{3}^{-}$to $\mathrm{CO}_{3}^{2-}$ (due to $\mathrm{CO}_{3}^{2-}$ uptake) and the direct uptake of $\mathrm{HCO}_{3}^{-}$have a similar effect on the $\mathrm{HCO}_{3}^{-}$profile.

Consequently, the calculated $\mathrm{CO}_{3}^{2-}$ and $\mathrm{pH}$ profiles are virtually identical for $r>400 \mu \mathrm{m}$. Close to the shell surface, however, $\mathrm{pH}$ increases for $\mathrm{HCO}_{3}^{-}$ uptake and decreases for $\mathrm{CO}_{3}^{2-}$ uptake, respectively.

\subsection{The $p H$-profile in O. universa}

The model was run to simulate a dark and light situation for $O$. universa corresponding to input parameters as measured by Rink (1996); see Table 2 .

The light and dark experiments were run for values reported for two particular specimens with a radius of the foraminiferal shell of 242 and $277 \mu \mathrm{m}$, respectively.

\subsubsection{Dark experiment}

The total respiration rate in the dark as measured by Rink (1996) was $3.4 \mathrm{nmol} \mathrm{O}_{2} \mathrm{~h}^{-1}$. Because the reported gross photosynthesis was $14 \mathrm{nmol} \mathrm{O}_{2} \mathrm{~h}^{-1}$, we can set the dark respiration of the symbiotic community at $1.4 \mathrm{nmol} \mathrm{O}_{2} \mathrm{~h}^{-1}$. Consequently, the respiration of the foraminifera becomes $2.0 \mathrm{nmol}$ $\mathrm{CO}_{2} \mathrm{~h}^{-1}$. The calcification rate in the dark experiment is given as $1 \mathrm{nmol} \mathrm{CO}_{3}^{2-} \mathrm{h}^{-1}$ (Lea et al., 1995).

Model results of the dark simulation for $O$. universa (Fig. 7, solid lines) are comparable with those for G. sacculifer. However, due to the higher calcification and respiration of $O$. universa (1.0 and 3.4 $\left.\mathrm{nmol} \mathrm{C} \mathrm{h}{ }^{-1}\right)$ in comparison to G. sacculifer ( 0.4 and $2.7 \mathrm{nmol} \mathrm{C} \mathrm{h}^{-1}$ ) the decrease in $\mathrm{pH}$ at the shell is more pronounced for $O$. universa. The $\mathrm{pH}$ decreases from 8.3 (bulk) to 7.9 at the shell surface. 

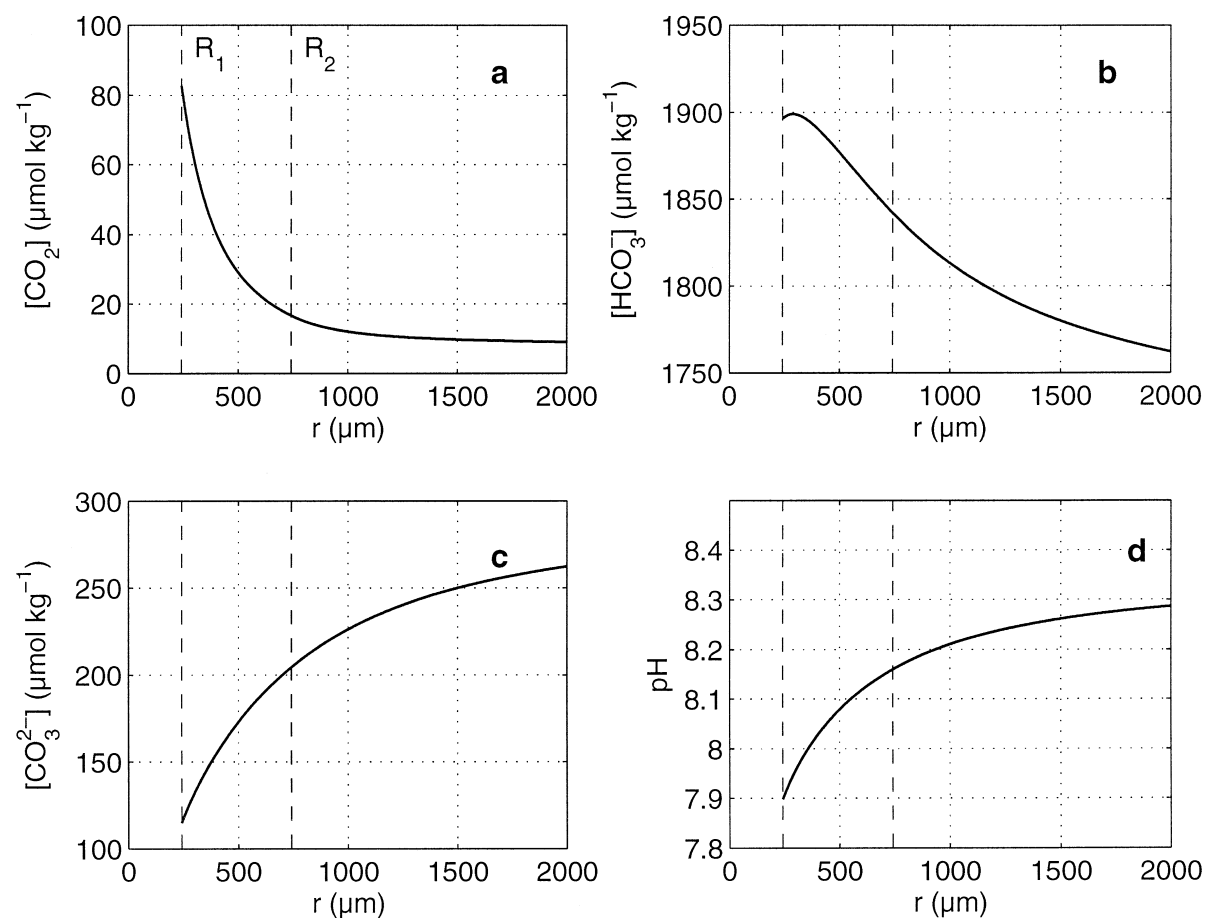

Fig. 7. O. universa: Model results of the carbon species and $\mathrm{pH}$ in the dark. The model run corresponds to a simulation with a shell radius of $242 \mu \mathrm{m}$ (see Rink, 1996). The calcification rate is $1 \mathrm{nmol} \mathrm{CO}_{3}^{2-} \mathrm{h}^{-1}$, while the respiration of the host-symbiont system is $3.4 \mathrm{nmol} \mathrm{CO}_{2}$ $\mathrm{h}^{-1}$.

\subsubsection{Light experiment}

The measured gross photosynthesis of $O$. universa was $14 \mathrm{nmol} \mathrm{O}_{2} \mathrm{~h}^{-1}$. Assuming a symbiont respiration of $1.4 \mathrm{nmol} \mathrm{CO}_{2} \mathrm{~h}^{-1}$ (see above), the net $\mathrm{O}_{2}$ production by photosynthesis is $12.6 \mathrm{nmol} \mathrm{O}_{2}$ $\mathrm{h}^{-1}$. Converted to carbon, the net uptake is then 9.9 $\mathrm{nmol} \mathrm{C} \mathrm{h} \mathrm{h}^{-1}$. The calcification rate in the light is 3 nmol $\mathrm{C} \mathrm{h}^{-1}$ (Lea et al., 1995). The model input for the respiration of the host-symbiont system in the light was $5.2(=3.8+1.4) \mathrm{nmol} \mathrm{CO}_{2} \mathrm{~h}^{-1}$ (Table 2).

The results of the light experiment for $O$. universa are presented in Fig. 8. In the first run we assumed a thickness of the symbiont halo of $500 \mu \mathrm{m}$ (solid lines). As a result of the lower photosynthetic rate $\left(9.9 \mathrm{nmol} \mathrm{C} \mathrm{h}^{-1}\right)$ and the larger radius of the shell $(277 \mu \mathrm{m})$ for $O$. universa in comparison to the model run for $G$. sacculifer $\left(12.7 \mathrm{nmol} \mathrm{C} \mathrm{h}^{-1}\right.$ and $200 \mu \mathrm{m})$ the $\mathrm{pH}$ increases towards the shell but drops below the ambient value at the shell. Unfortunately, there are no measurements of a $\mathrm{pH}$ profile which can directly be compared to the model output. Measured profiles for $O$. univers $a$ in the light consistently show an increase of $\mathrm{pH}$ towards the shell. A possible explanation for the discrepancy between observed profiles and model results might be attributed to the thickness of the symbiont halo on the model outcome.

The results of a model run, assuming a thickness of the symbiont halo of $100 \mu \mathrm{m}$, is also shown in Fig. 8 (broken lines). The $\mathrm{CO}_{2}$ concentration at the shell for the thin halo is significantly smaller than for the thick halo because the $\mathrm{CO}_{2}$ uptake near the shell has increased through the higher symbiont density in the thin halo. Consequently, the $\mathrm{pH}$ is increasing towards the foraminiferal shell. Since a considerable portion of the symbionts of $O$. universa is often located close to or within the foraminiferal shell during microelectrode measurements, the actual thickness of the symbiont halo is probably much smaller than $500 \mu \mathrm{m}$. This scenario could therefore explain the differences between model results and 

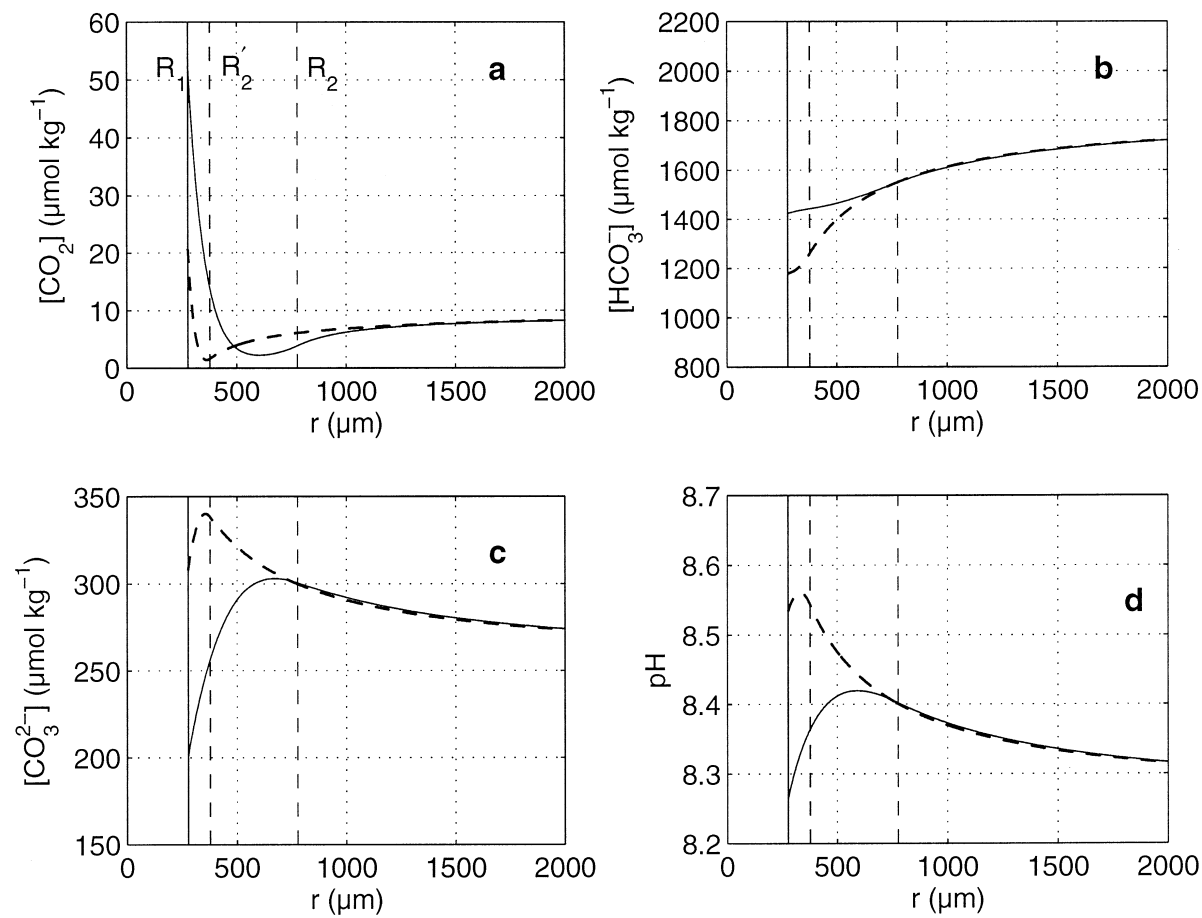

Fig. 8. O. universa: Model results of the carbon species and $\mathrm{pH}$ of a simulation for $O$. universa with a shell radius of $277 \mu \mathrm{m}$ in the light (see Rink, 1996). The calcification rate is $3 \mathrm{nmol} \mathrm{CO}_{3}^{2-} \mathrm{h}^{-1}$, the net carbon uptake of symbionts by photosynthesis is $9.9 \mathrm{nmol} \mathrm{C} \mathrm{h}^{-1}$, and the respiration of the host-symbiont system is $5.2 \mathrm{nmol} \mathrm{CO}_{2} \mathrm{~h}^{-1}$. The solid lines correspond to a thickness of the symbiont halo of $500 \mu \mathrm{m}$ whereas the broken lines correspond to a thickness of the symbiont halo of $100 \mu \mathrm{m}$. The lower symbiont activity near the shell for the thicker halo $(500 \mu \mathrm{m})$ might explain the drop in $\mathrm{pH}$ at the shell which is not observed in the $\mathrm{pH}$ profiles measured with micro-electrodes.

measurements. It should be noted that the symbiont halo in undisturbed foraminifera can be out 1000 or even $1500 \mu \mathrm{m}$. In such situations the halo does not start at the shell surface but at some distance away from the surface.

\section{Summary and conclusions}

In this paper a diffusion-reaction model of the marine carbonate system (Wolf-Gladrow and Riebesell, 1997) has been applied to the microenvironment of symbiont bearing foraminifera. The influence of uptake or production of carbonate species as consequences of calcification, photosynthesis and respiration, was studied. G. sacculifer and O. universa were used as model species. For typical carbon fluxes associated with calcification, photosynthesis or respiration the components of the carbonate system show dramatic changes of their concentrations.
The carbonate concentration, for example, drops below half of its bulk concentration when the foraminifer is calcifying. Negative and positive deviations of $\mathrm{pH}$ for dark (no photosynthesis) and light conditions compare quite well with microelectrode measurements. The supply of $\mathrm{CO}_{2}$ from the bulk medium and respiration of the foraminifer is not sufficient to support the observed rates of photosynthesis. Thus the dinoflagellate symbionts must rely on other carbon sources, most likely bicarbonate.

Model results of the current paper clearly show that the foraminiferal shells 'do not see' the bulk carbonate chemistry directly. Instead, the carbonate system is strongly modified by 'vital processes'. Could this be the answer to the question of the carbon and oxygen fractionation mechanisms as suggested by Spero et al. (1997) and Bijma et al. (in press)? This problem is addressed in the companion paper by Zeebe et al. (1999) and in Zeebe (in press). 


\section{Acknowledgements}

We thank Stephanie Rink for sharing her microelectrode data with us and Bo Barker Jørgensen for providing unpublished $\mathrm{pH}$ data. Hein de Baar, Howie Spero and an anonymous referee are acknowledged for many critical comments which improved the manuscript. This is publication number 1419 of the Alfred Wegener Institute for Polar and Marine Research and SFB-261 publication number 243.

\section{References}

Anderson, O.R., Faber, W.W. Jr., 1984. An estimation of calcium carbonate deposition rate in a planktonic foraminifer Globigerinoides sacculifer using ${ }^{45} \mathrm{Ca}$ as a tracer: A recommended procedure for improved accuracy. J. Foram. Res. 14 (4), 303-308.

Bé, A.W.H., 1980. Gametogenic calcification in a spinose planktonic foraminifer, Globigerinoides sacculifer (Brady). Marine Micropaleontology 5, 283-310.

Bé, A.W.H., Hemleben, C., Anderson, O.R., Spindler, M., 1979. Chamber formation in planktonic foraminifera. Micropaleontology 25 (3), 294-306.

Bé, A.W.H., Anderson, O.R., Faber, W.W. Jr., 1983. Sequence of morphological and cytoplasmic changes during gametogenesis in the planktonic foraminifer Globigerinoides sacculifer (Brady). Micropaleontology 29 (3), 310-325.

Berger, W.H., 1969. Planktonic foraminifer: basic morphology and ecologic implications. J. Paleontology 43 (6), 1369-1384.

Bijma, J., 1986. Observations on the life history and carbon cycling of planktonic foraminifera Gulf of Eilat/Aqaba. Master's thesis, State University Groningen, the Netherlands, pp. $1-121$.

Bijma, J., Erez, J., Hemleben, C., 1990a. Lunar and semi-lunar reproductive cycles in some spinose planktonic foraminifers. Journal of Foraminiferal Research 20 (2), 117-127.

Bijma, J., Faber, W.W. Jr., Hemleben, C., 1990b. Temperature and salinity limits for growth and survival of some planktonic foraminifers in laboratory cultures. Journal of Foraminiferal Research 20 (2), 95-116.

Bijma, J., Spero, H.J., Lea, D.W., Bemis, B.E., in press. Reassessing foraminiferal stable isotopes: Effects of seawater carbonate chemistry. In: Fischer, G., Wefer, G. (Eds.), Proxies in Paleoceanography. Springer.

Chen, C.Y., Durbin, E.G., 1994. Effects of pH on the growth and carbon uptake of marine phytoplankton. Marine Ecology Progress Series 109, 83-94.

Duplessy, J.C., Lalou, C.C., Vinot-Bertouille, A.C., 1970. Differential isotopic fractionation in benthic foraminifera and paleotemperature, reassesed. Science 168, 250-251.

Erez, J., 1983. Calcification rates, photosynthesis and light in planktonic foraminifera. In: Westbroek, P., de Jong, E.W.
(Eds.), Biomineralization and biological metal accumulation. Reidel, pp. 307-312.

Gastrich, M.D., 1988. Ultrastructure of a new intracellular symbiotic alga found within planktonic foraminifera. Journal of Phycology 23, 623-632.

Hamilton, C.P., 1997. Gametogenic calcification in the planktonic foraminifera. Orbulina universa and glacial to interglacial sea surface temperatures across the subtropical convergence in the southwest Pacific Ocean. Master's thesis, University of California Davis, $183 \mathrm{pp}$.

Hemleben, C., Spindler, M., Breitinger, I., Ott, R., 1987. Morphological and physiological responses of Globigerinoides sacculifer (Brady) under varying laboratory conditions. Marine Micropaleontology 12 (4), 305-324.

Hemleben, C., Spindler, M., Anderson, O.R., 1989. Modern Planktonic Foraminifera. Springer-Verlag, New York.

Hinga, K.R., 1992. Co-occurrence of dinoflagellate blooms and high $\mathrm{pH}$ in marine enclosures. Mar. Ecol. Prog. Ser. 86, $181-187$.

Humphrey, G.F., 1975. The photosynthesis:respiration ratio of some unicellular marine algae. J. Exp. Mar. Biol. Ecol. 18, $111-119$.

Jørgensen, B.B., Erez, J., Revsbech, N.P., Cohen, Y., 1985. Simbiotic photosynthesis in a planktonic foraminiferan, Globigerinoides sacculifer (Brady), studied with microelectrodes. Limnol. Oceanogr. 30 (6), 1253-1267.

Lea, D.W., Martin, P.A., Chan, D.A., Spero, H.J., 1995. Calcium uptake and calcification rate in the planktonic foraminifera Orbulina universa. Journal of Foraminiferal Research 25 (1), 14-23.

Lowenstam, H.A., Weiner, S., 1989. On Biomineralization. Oxford Univ. Press, New York.

Mann, S., Webb, J., Williams, R.J.P., (Eds.), 1989. Biomineralization: Chemical and Biochemical Perspectives. VCH, Weinheim.

Ploug, H., Kühl, M., Buchholz-Cleven, B., Jørgensen, B.B., 1997. Anoxic aggregates - an ephemeral phenomenon in the pelagic environment?. Aquat. Microb. Ecol. 13, 285-294.

Rau, G.H., Riebesell, U., Wolf-Gladrow, D., 1996. A model of photosynthetic ${ }^{13} \mathrm{C}$ fractionation by marine phytoplankton based on diffusive molecular $\mathrm{CO}_{2}$ uptake. Marine Ecology Progress Series 133, 275-285.

Redfield, A.C., Ketchum, B.H., Richards, F.A., 1963. The influence of organisms on the composition of seawater. In: Hill, M.N. (Ed.), The Sea, Vol. 2. Interscience, New York, pp. $1-34$.

Riebesell, U., Wolf-Gladrow, D., Smetacek, V., 1993. Carbon dioxide limitation of marine phytoplankton growth rates. Nature 361, 249-251.

Rink, S., 1996. Untersuchung der Photosynthese und Respiration der symbiontentragenden planktischen Foraminifere Orbulina universa mit Mikroelektroden. Master's thesis, Universität Bremen.

Rink, S., Kühl, M., Bijma, J., Spero, H., 1998. Microsensor studies of photosynthesis and respiration in the symbiotic foraminifer Orbulina universa. Marine Biology 131, 583-595.

Sanyal, A., Hemming, N.G., Hanson, G.N., Broecker, W.S., 1995. 
Evidence for a higher $\mathrm{pH}$ in the glacial ocean from boron isotopes in foraminifera. Nature 373, 234-236.

Signes, M., Bijma, J., Hemleben, C., Ott, R., 1993. A model for planktic foraminiferal shell growth. Paleobiology 19 (1), 7191.

Spero, H.J., Parker, S.L., 1985. Photosynthesis in the symbiotic planktonic foraminifer Orbulina universa, and its potential contribution to oceanic primary productivity. J. Foram. Res. 15 (4), 273-281.

Spero, H.J., Williams, D.F., 1988. Extracting environmental information from planktonic foraminiferal $\delta^{13} \mathrm{C}$ data. Nature 335, 717-719.

Spero, H.J., Lerche, I., Williams, D.F., 1991. Opening the carbon isotope 'vital effect' black box: 2. Quantitative model for interpreting foraminiferal carbon isotope data. Paleoceanography $6(6), 639-655$.

Spero, H.J., Bijma, J., Bemis, B., Lea, D., 1997. Effect of seawater carbonate concentration on foraminiferal carbon and oxygen isotopes. Nature 390, 497-500.
Spindler, M., Hemleben, C., Salomons, J.B., Smit, L.P., 1984. Feeding behavior of some planktonic foraminifers in laboratory cultures. J. Foram. Res. 14 (4), 237-249.

ter Kuile, B., 1991. Mechanisms for calcification and carbon cycling in algal symbiont-bearing foraminifera. In: Lee, J.J., Anderson, O.R. (Eds.), Biology of Foraminifera. Academic Press, pp. 73-89.

ter Kuile, B., Erez, J., 1988. The size and function of the internal inorganic carbon pool of the foraminifer Amphistegina lobifera. Marine Biology 99, 481-487.

Wolf-Gladrow, D.A., Riebesell, U., 1997. Diffusion and reactions in the vicinity of plankton: a refined model for inorganic carbon transport. Marine Chemistry 59, 17-34.

Zeebe, R.E., An explanation of the effect of seawater carbonate concentration on foraminiferal oxygen isotopes. Geochim. Cosmochim. Acta, in press.

Zeebe, R.E., Bijma, J., Wolf-Gladrow, D.A., 1999. A diffusion-reaction model of carbon isotope fractionation in foraminifera. Marine Chemistry 64, 199-228. 